\title{
Associations and communities of cereal crops of the Łuków Plain. Part III. Intermediate and impoverished communities
}

\author{
Zofia Rzymowska*, Teresa Skrajna \\ Department of Agricultural Ecology of the Siedlce University of Nature Sciences and Humanities, B. Prusa 14, 08-110 Siedlce, Poland
}

\begin{abstract}
The paper is the third and final part of the work attempting to analyze associations and communities in cereal crops of the Łuków Plain. It contains a description of intermediate and impoverished communities establishing in cereal crops of the Łuków Plain. Patches with phytocenoses without the combination of species characteristic of cereal associations were frequently observed. Impoverished communities of the alliance Aperion spicae-venti established in winter cereal crops. In turn, in spring cereal crops phytocenoses including species characteristic of the tuber and root crops were found which represented either a community with species characteristic of Panico-Setarion or an intermediate community with species characteristic of Aperion spicae-venti and Polygono-Chenopodion. Such communities establish, among others, because of production intensification which changes habitat conditions. Some patches found in the study area were intermediate between the two most frequently observed associations Arnoserido-Scleranthetum and Vicietum tetraspermae.
\end{abstract}

Keywords: segetal vegetation; cereal associations; transitional communities; impoverished communities

\section{Introduction}

Many patches of cereal communities in the Łuków Plain area represent phytocenoses which are difficult to unambiguously define in phytosociological terms. They are usually impoverished communities which do not contain species characteristic of cereal associations. Intermediate communities, which establish in the ecotonal area between two adjacent associations, are less frequent. It is these phytocenoses that the present paper is focused on. It is the third part of the work "Associations and communities in cereal crops of the Euków Plain" so it does not contain the methodology which was presented in the first part of the aforementioned work [1]. Description of the Łuków Plain cereal communities was based on 79 phytosociological relevés following the Braun-Blanquet approach [2]. The aim of the present paper is to analyze the structure, floristic composition and syntaxonomic diversity of intermediate communities and impoverished phytocenoses establishing under conditions of intensive field farming (increased anthropopression).
* Corresponding author. Email: zrzymowska@wp.pl

Handling Editor: Elżbieta Weryszko-Chmielewska

\section{Results}

Systematic of the distinguished cereal communities

Class: Stellarietea mediae Tx., Lohm. et Prsg. 1950

Order: Centauretalia cyani R. Tx. 1950

Alliance: Aperion spicae-venti R. Tx. et J. Tx. 1960

Intermediate community Arnoserido-Scleranthetum (Edouard 1925) R. Tx. 1937 - Vicietum tetraspermae (Krusem. et Vlieg 1939) Kornaś 1950

Community with Scleranthus annuus

Community with characteristic species of Aperion spicae-venti

Order: Polygono-Chenopodietalia (R. Tx. et Lohm. 1950) J. Tx. 1961

Alliance: Panico-Setarion Siss. 1946

Community with characteristic species of Panico-Setarion

\section{Characteristics of the distinguished communities}

In the Łuków Plain area, apart from well established patches of cereal associations, there were found both intermediate and impoverished communities without species characteristic of cereal associations. They included: the community intermediate between the associations Arnoserido-Scleranthetum and Vicietum tetraspermae, the community with Scleranthus annuus and phytocenoses with the characteristic species Aperion spicae-venti and Panico-Setarion. 


\section{Arnoserido-Scleranthetum - Vicietum tetraspermae}

Patches of a community intermediate between the associations Arnoserido-Scleranthetum and Vicietum tetraspermae are found quite often because phytocenoses of both the associations are popular in the study area. The analyzed phytocenoses establish in rye crops on pseudo-podzolic and leached brown soils classified as either the rye weak or cerealfodder weak soil quality complex. They are slightly loamy sands or light loamy sands usually on loose sand (Tab. 1).

Species characteristic of Arnoseris minima and Vicia tetrasperma were similarly frequent and had quite a high cover. The share of other characteristic and differential species of these associations was low. Vicia villosa was the only species that was quite popular in the aforementioned associations. These phytocenoses were dominated by Scleranthus annuus, Anthemis arvensis and Rumex acetosella, which indicates that the habitats are acidified. Moreover, the species Apera spica-venti was found in large numbers. Hygrophilous species established in patches on soils belonging to the cereal-fodder weak soil quality complex.

Altogether there were found 60 species in the analyzed phytocenoses, the average number per one relevé being 16 (Tab. 1).

\section{Community with Scleranthus annuus}

Patches of this community were observed in the poorest habitats, on soils belonging to the rye very weak, rye wear and cereal-fodder weak soil quality complexes (Tab. 1). The community was acidophilous in character, as indicated by an occurrence of the following differential species: Scleranthus annuus, Rumex acetosella and Anthemis arvensis. These phytocenoses were primarily dominated by the first two species. The alliance and order were, first and foremost, represented by Apera spica-venti and Centaurea cyanus.

The analyzed community was the species-poorest of all the cereal communities in this area. The overall number of species was only 43 ; the average number per one relevé was 10 .

\section{Community with characteristic species of Aperion spicae-venti}

Among the impoverished phytocenoses in the study area there were frequently found patches of communities without species characteristic of cereal associations which included a large number of species characteristic of the alliance Aperion spicae-venti. Due to floristic diversity reflecting changeable habitat conditions, three forms of this community were distinguished: typical, with hygrophilous species, and with species characteristic of Polygono-Chenopodion (Tab. 1).

Patches typical of this community were most frequently found in the study area. They established on various soil types and kinds classified as either the rye weak, rye good or rye very good soil quality complex. Great numbers of Apera spica-venti were found in these phytocenoses. The alliance and order were predominantly represented by Centaurea cyanus, Vicia angustifolia, V. hirsuta and Anthemis arvensis, the most frequent species characteristic of the class being Viola arvensis and Myosotis arvensis. The share of the remaining species was low. The overall number of species in typical patches was 68 . The number of species per one relevé was 6-22, 12 on average (Tab. 1).
The form of this community with hygrophilous species was observed in more fertile habitats, compared with the typical form. The analyzed communities established on leached brown soils, pseudo-podzolic soils, true and degraded chernozems classified as the strong or weak cereal-fodder complexes, good or very good rye complexes or good wheat complex (Tab. 1). These patches, just like typical patches, were also dominated by Apera spica-venti. However, numerous species characteristic of fertile habitats were found, the most frequent being Matricaria maritima subsp. inodora. Papaver rhoeas, Consolida regalis, Anagallis arvensis were popular, too, but not so frequent. In some places a high share of Galium aparine was recorded, too. A high frequency of the above-mentioned species and an occurrence of other less popular species indicate that they are nutrient-rich habitats. There were also found numerous hygrophilous species, of which Juncus bufonius and Plantago intermedia were the most constant and popular. The analyzed phytocenoses were much richer floristically than the typical ones. Overall, there were found 91 species. The number of species per relevé was from 12 to 28,21 on average.

Patches of the community Aperion spicae-venti, including species characteristic of Polygono-Chenopodion, established in spring cereals on different soil types. These soils were characterized by a more compact grain-size distribution, usually developed from sandy loams or heavy loamy sands on sandy loam, classified as the very good rye complex, the good wheat complex, or cereal-fodder complexes, of the latter the strong cereal-fodder complex being the most frequent (Tab. 1).

Compared with the aforementioned communities, Apera spica-venti was less frequently found in the communities discussed. Species characteristic of the alliance Aperion spicae-venti were numerous, the most frequent being PolygonoChenopodion species which are characteristic of tuber and root crops. Matricaria maritima subsp. inodora, Avena fatua and Centaurea cyanus were the species characteristic of cereal crops which were the most constant and frequently found whereas Veronica persica, Galinsoga parviflora, Lamium purpureum were Polygono-Chenopodion representatives with such properties. Sonchus asper, S. oleraceus and Oxalis fontana were less frequently found. Also, an occurrence of Chenopodium album, Galium aparine and Stellaria media in these habitats indicates that they are rich in nitrogen. These habitats were temporarily too wet, as indicated by an occurrence of hygrophilous species, Juncus bufonius and Plantago intermedia in particular. These phytocenoses were floristically rich as 105 species were found in total. The number of species per relevé ranged from 14 to 39, 23 on average.

\section{Community with characteristic species of Panico-Setarion}

Phytocenoses whose floristic composition was similar to tuber and root crop communities established in spring cereals on various types of soils classified as the weak rye complex, good wheat complex and cereal-fodder complexes (Tab. 1). The soil had different compactness, and ranged from light loamy sands and heavy loamy sands to sandy loams. There were found few species characteristic of Aperion spicae$v e n t i$ in the analyzed communities, the only representatives of this syntaxonomic group being Matricaria maritima subsp. 
Tab. 1 Intermediate and impoverished communities of cereal cultivations of the Łukowska Plain.

\begin{tabular}{|c|c|c|c|c|c|c|}
\hline Community & $\begin{array}{c}\text { Arnoserido- } \\
\text { Scleranthetum- } \\
\text { Vicietum }\end{array}$ & $\begin{array}{c}\text { with Scleranthus } \\
\text { annuus }\end{array}$ & \multicolumn{3}{|c|}{ Aperion spicae-venti } & \multirow{2}{*}{$\begin{array}{c}\text { Panico-Setarion } \\
\text { typical }\end{array}$} \\
\hline Form & typical & typical & typical & $\begin{array}{l}\text { with Juncus } \\
\text { bufonius }\end{array}$ & $\begin{array}{l}\text { with Polygono- } \\
\text { Chenopodion }\end{array}$ & \\
\hline Number of relevés & 10 & 10 & 20 & 10 & 19 & 10 \\
\hline \multirow[b]{3}{*}{ Soil unit } & 6,9 & $7,6,9$ & $6,5,4$ & $5,4,2,8,9$ & $4,2,8,9$ & $6,2,8,9$ \\
\hline & $\mathrm{A}, \mathrm{Bw}$ & $\mathrm{A}, \mathrm{Bw}$ & $\mathrm{A}, \mathrm{Bw}, \mathrm{D}$ & A, Bw, M, Dz, D & $\mathrm{A}, \mathrm{Bw}, \mathrm{B}, \mathrm{Dz}, \mathrm{D}$ & A, Bw, D \\
\hline & $\begin{array}{l}\text { ps; pgl:pl; pgl.pl; } \\
\text { pgl:ps }\end{array}$ & $\begin{array}{l}\text { pl; ps.pl; ps; pgl. } \\
\text { pl; pgl:pl }\end{array}$ & $\begin{array}{l}\text { ps; pgl.pl; pgl:pl; } \\
\text { pgl.ps; pgl:gl; } \\
\text { pgm.gs; płz; } \\
\text { płz:gl; glp }\end{array}$ & $\begin{array}{l}\text { psp; pgl.pl.płz; } \\
\text { pgl:pl; pgl:ps; } \\
\text { pglp:ps; pgm.gl; } \\
\text { pgmp; gl; glp }\end{array}$ & $\begin{array}{l}\text { pgm.ps; pgm:gl; } \\
\text { pgmp; płz:ps; } \\
\text { płz; glp; gl }\end{array}$ & $\begin{array}{l}\text { pgl.pl; pglp; } \\
\text { pgl:gs; pgm:ps; } \\
\text { pgm:gl; } \\
\text { pgmp:ps; pgmp; } \\
\text { glp; gl }\end{array}$ \\
\hline $\begin{array}{r}\text { Range of number species in } \\
\text { relevés }\end{array}$ & $10-25$ & $8-13$ & $6-22$ & $12-28$ & $14-39$ & $15-38$ \\
\hline $\begin{array}{r}\text { Mean number of species in } \\
\text { relevé }\end{array}$ & 16 & 10 & 12 & 21 & 23 & 24 \\
\hline \multirow[t]{2}{*}{ Number of columns } & 1 & 2 & 3 & 4 & 5 & 6 \\
\hline & $\mathrm{W}$ & $\mathrm{W}$ & W & W & $\mathrm{W}$ & W \\
\hline
\end{tabular}

\section{Ch. D. Arnoserido-Scleranthetum}

\begin{tabular}{llllllllll}
\hline Arnoseris minima & V & 300 & & & I & 5 & & \\
Scleranthus annuus & V & 705 & V & 2500 & I & 40 & I & 10 & I
\end{tabular}

\section{Ch. D. Vicietum tetraspermae}

\begin{tabular}{|c|c|c|c|c|c|c|c|c|c|c|c|c|}
\hline Vicia tetrasperma & $\mathrm{V}$ & 300 & & & & & & & & & & \\
\hline Vicia villosa & III & 140 & II & 40 & I & 218 & & & & & & \\
\hline $\begin{array}{l}\text { Polygonum lapathifolium subsp. } \\
\text { pallidum }\end{array}$ & $\mathrm{I}$ & 20 & & & & & $\mathrm{I}$ & 20 & II & 27 & II & 205 \\
\hline
\end{tabular}
pallidum

\section{Ch. Aperion spicae-venti,Centauretalia cyani}

\begin{tabular}{|c|c|c|c|c|c|c|c|c|c|c|c|c|}
\hline Apera spicae-venti & IV & 895 & IV & 355 & $\mathrm{~V}$ & 1288 & $\mathrm{~V}$ & 1070 & IV & 567 & IV & 110 \\
\hline Anthemis arvensis & IV & 1020 & $\mathrm{~V}$ & 210 & III & 198 & II & 40 & I & 20 & III & 130 \\
\hline Centaurea cyanus & III & 225 & IV & 210 & $\mathrm{~V}$ & 208 & III & 140 & II & 120 & II & 40 \\
\hline Matricaria maritima subsp. inodora & II & 110 & I & 10 & II & 143 & IV & 895 & $\mathrm{~V}$ & 193 & IV & 200 \\
\hline Vicia angustifolia & IV & 150 & I & 10 & IV & 130 & II & 80 & I & 13 & II & 40 \\
\hline Vicia hirsuta & $\mathrm{I}$ & 20 & & & III & 493 & III & 130 & $\mathrm{I}$ & 47 & I & 20 \\
\hline Papaver rhoeas & & & & & I & 93 & IV & 50 & I & 73 & & \\
\hline Avena fatua & & & & & I & 10 & I & 10 & II & 177 & III & 495 \\
\hline Consolida regalis & & & & & I & 5 & II & 110 & $\mathrm{I}$ & 7 & & \\
\hline
\end{tabular}

\section{Ch. Panico-Setarion}

Echinochloa crus-gall

Raphanus raphanistrum

20

$\begin{array}{rrrr}\text { II } & 60 & \text { V } & 1685 \\ \text { I } & 20 & \text { II } & 30 \\ & & \text { II } & 30\end{array}$

Setaria pumila

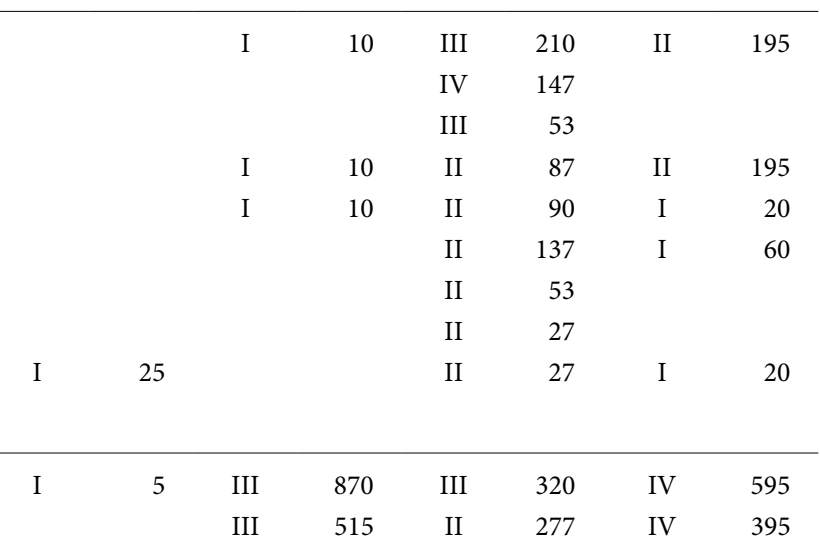


Tab. 1 (continued)

\begin{tabular}{|c|c|c|c|c|c|c|c|c|c|c|c|c|}
\hline Plantago intermedia & I & 50 & & & & & I & 20 & III & 320 & IV & 150 \\
\hline Polygonum hydropiper & I & 20 & & & & & I & 60 & & & III & 305 \\
\hline Rorippa sylvestris & & & & & & & II & 30 & I & 73 & II & 30 \\
\hline Sagina procumbens & I & 10 & & & & & I & 10 & I & 13 & II & 70 \\
\hline Spergularia rubra & I & 100 & I & 50 & & & II & 70 & & & I & 10 \\
\hline Potentilla anserina & I & 10 & & & & & I & 20 & II & 33 & I & 20 \\
\hline Ranunculus sardous & & & & & I & 5 & I & 60 & II & 80 & & \\
\hline Gypsophila muralis & & & & & & & II & 30 & I & 40 & I & 10 \\
\hline Centunculus minimus & & & & & & & I & 20 & I & 33 & II & 30 \\
\hline \multicolumn{13}{|l|}{ VII. Ch. Stellarietea mediae } \\
\hline Viola arvensis & III & 100 & III & 50 & $\mathrm{~V}$ & 150 & III & 100 & III & 60 & IV & 70 \\
\hline Myosotis arvensis & II & 40 & I & 10 & IV & 70 & III & 50 & III & 80 & III & 50 \\
\hline Stellaria media & & & I & 10 & I & 10 & I & 20 & III & 107 & IV & 200 \\
\hline Polygonum aviculare & I & 10 & I & 10 & I & 10 & I & 20 & II & 40 & IV & 110 \\
\hline Fallopia convolvulus & I & 10 & III & 50 & I & 15 & II & 30 & II & 33 & III & 100 \\
\hline Capsella bursa-pastoris & I & 20 & & & III & 50 & I & 10 & III & 87 & III & 60 \\
\hline Conyza canadensis & III & 60 & II & 195 & II & 45 & II & 30 & II & 27 & & \\
\hline Chenopodium album & I & 10 & I & 10 & I & 20 & II & 70 & III & 287 & II & 70 \\
\hline Spergula arvensis & I & 50 & II & 30 & I & 10 & II & 30 & I & 7 & II & 30 \\
\hline Galeopsis tetrahit & & & & & I & 5 & III & 50 & I & 7 & I & 10 \\
\hline Anagallis arvensis & & & & & I & 30 & II & 70 & I & 73 & II & 120 \\
\hline Sonchus arvensis & & & & & I & 5 & I & 20 & II & 27 & I & 20 \\
\hline \multicolumn{13}{|l|}{ VIII. Accompanying species } \\
\hline Rumex acetosella & IV & 315 & IV & 730 & I & 35 & I & 10 & & & I & 20 \\
\hline Veronica arvensis & II & 30 & & & III & 70 & II & 80 & IV & 93 & IV & 70 \\
\hline Cirsium arvense & II & 80 & & & II & 30 & III & 60 & III & 80 & I & 20 \\
\hline Elymus repens & I & 10 & & & II & 45 & II & 120 & III & 80 & III & 140 \\
\hline Galium aparine & I & 10 & & & I & 40 & II & 445 & III & 153 & II & 120 \\
\hline Equisetum arvense & I & 60 & II & 30 & II & 25 & II & 30 & II & 27 & III & 50 \\
\hline Convolvulus arvensis & I & 20 & II & 30 & I & 15 & II & 40 & II & 27 & I & 10 \\
\hline Avena strigosa & I & 50 & & & I & 10 & & & II & 80 & I & 10 \\
\hline $\begin{array}{l}\text { Polygonum lapathifolium subsp. } \\
\text { lapathifolium }\end{array}$ & I & 10 & & & & & I & 60 & II & 27 & II & 40 \\
\hline Artemisia vulgaris & & & & & I & 5 & II & 30 & II & 33 & I & 10 \\
\hline Poa annua & I & 10 & & & & & I & 10 & & & II & 40 \\
\hline Trifolium repens & I & 10 & & & & & I & 10 & I & 13 & II & 30 \\
\hline Chamomilla suaveolens & & & & & I & 5 & & & I & 47 & II & 30 \\
\hline Daucus carota & & & & & I & 0 & II & 0 & I & 0 & & \\
\hline Plantago major & & & & & & & I & 0 & I & 7 & II & 30 \\
\hline Polygonum persicaria & & & & & & & I & 20 & & & II & 80 \\
\hline
\end{tabular}

Fig. 1 Sporadic species: I - Veronica dillenii 1, 2, 3, 5; Holcus mollis 1, 4; Anthoxanthum aristatum 1; II - Bromus secalinus 3, 5; III Arabidopsis thaliana 1, 2, 3, 4, 6; Agrostemma githago 2, 3, 4; Rhinanthus serotinus 1, 3; Chamomilla recutita 1, 3; Odontites serotina 1, 4; Melandrium noctiflorum 4, 5; Aethusa cynapium 5; IV - Setaria viridis 6; V - Geranium pusillum 2, 5, 6; Chenopodium polyspermum 5, 6; Galinsoga ciliata 5, 6; Solanum nigrum 5, 6; Veronica polita 5; Lamium amplexicaule 5; Atriplex patula 5; VI - Ranunculus repens 1, 4, 5, 6; Mentha arvensis 1, 4, 5; Polygonum amphibium 2, 3, 5; Bidens tripartita 4, 5, 6; Peplis portula 4, 5, 6; Veronica serpyllifolia 4, 5, 6; Stachys palustris 4, 5; Riccia sp. 4, 6; Rorippa palustris 4, 6; Anthoceros punctatus 4; Centaurium pulchellum 5; Phragmites australis 5; VII - Sinapis arvensis 3, 4, 5; Descurainia sophia 3, 4, 5; Sisymbrium officinale 3, 4, 5; Thlaspi arvense 4, 5; Rumex crispus 5, 6; Anchusa arvensis 3; Crepis tectorum 5; Galeopsis speciosa 5; Lactuca serriola 6; VIII - Cerastium holosteoides 1, 2, 3, 4, 5; Taraxacum officinale 1, 3, 4, 5, 6; Agrostis stolonifera 1, 3, 4, 5; Trifolium campestre 3, 4, 5, 6; Arenaria serpyllifolia 1, 2, 3; Erophila verna 1, 2, 3; Knautia arvensis 1, 2, 3; Holcus lanatus 1, 2, 4; Stellaria graminea 1, 2, 5; Achillea millefolium 1, 3, 5; Myosotis stricta 2, 3, 4; Erysimum cheiranthoides 4, 5, 6; Alopecurus myosuroides 4, 5, 6; Erodium cicutarium 1, 2; Cerastium semidecandrum 1, 4; Trifolium arvense 2, 3; Hypericum perforatum 2, 3; Plantago lanceolata 2, 6; Medicago lupulina 4, 5; Leontodon autumnalis 4, 5; Phleum pratense 4, 5; Senecio vulgaris 4, 5; Veronica verna 4, 5; Galeopsis bifida 5, 6; Galeopsis pubescens 5, 6; Prunella vulgaris 5, 6; Galeopsis ladanum 1; Trifolium dubium 1; Artemisia campestris 2; Carex hirta 2; Allium vineale 2; Jasione montana 2; Oenothera biennis 2; Artemisia absinthium 2; Euphorbia cyparissias 2; Lolium perenne 3; Berteroa incana 3; Cichorium intybus 3; Heracleum sphondylium 3; Hypochoeris radicata 3; Rumex obtusifolius 3; Vicia cracca 3; Pastinaca sativa 3; Melandrium album 4; Ranunculus flammula 4; Epilobium roseum 4; Trifolium pratense 4; Veronica chamaedrys 4; Phalaris arundinacea 4; Potentilla collina 4; Ballota nigra 4; Chenopodium glaucum 5; Armoracia rusticana 5; Dactylis glomerata 5; Holosteum umbellatum 5; Lysimachia nummularia 5; Sinapis alba 5; Potentilla reptans 5; Epilobium ciliatum 6. 
inodora and Apera spica-venti. In places more Avena fatua plants were found. These phytocenoses were dominated by Echinochloa crus-galli. The remaining Panico-Setarion representatives were rare and characterized by a small cover. In some patches more Galinsoga parviflora and Oxalis fontana plants were found. Moreover, Stellaria media and Polygonum aviculare were frequent components of these communities which also included hygrophilous species, for example: Juncus bufonius, Gnaphalium uliginosum, Plantago intermedia and Polygonum hydropiper. The overall number of species in these phytocenoses was 76 . The number of species per relevé was from 15 to 38,24 on average.

\section{Discussion}

In the area of the Łuków Plain well established patches of cereal crop associations [1] were often accompanied by impoverished phytocenoses without characteristic species of known cereal associations. These communities are a degradative form of typical patches establishing under conditions of stronger anthropogenic impact [3,4]. Production intensification not only directly changes trophic conditions of a given habitat but also, by increasing stand density, indirectly affects many other factors which influence phytocenoses $[4,5]$ such as moisture, thermal and light conditions, and also increases competition of crop plants. What is more, sowing of certified seeds or improved seed cleaning and using more effective weed control methods cause more sensitive species, including characteristic species, to disappear from cereal crop communities [6-10]. It leads to impoverished species composition and negatively influences biodiversity of segetal communities. What is more, there is observed a higher share of herbicide-resistant species characterized by a wide ecological amplitude [11-13]. This process in the study area was reflected in an occurrence of impoverished communities including characteristic species of Aperion spicae-venti and communities with Scleranthus annuus. Such phytocenoses are often found in Poland [14-21].

\section{Acknowledgments}

Research supported by the Ministry of Science and Higher Education of Poland as the part of statutory activities of Department of Agricultural Ecology, Siedlce University of Natural Sciences and Humanities.

\section{Authors' contributions}

The following declarations about authors' contributions to the research have been made: concept of the study: ZR, ST; field work: ZR, ST; data analysis: ZR, ST; writing of the manuscript: ZR, ST.

\section{Competing interests}

No competing interests have been declared.

\section{References}

1. Rzymowska Z, Skrajna T. Associations and communities of the cereal crops of the Łuków Plain. Part. I. Light soil associations. Acta Agrobot. 2011;64(4):243-250. http://dx.doi.org/10.5586/aa.2011.066

2. Pawłowski B. Skład i budowa zbiorowisk roślinnych oraz metody ich badania. In: Szafer W, Zarzycki K, editors. Szata roślinna Polski. Warsaw: Polish Scientific Publishers PWN; 1972. p. 237-268. (vol 1).
Special habitat conditions in spring cereal stands, in particular thermal and light conditions which are much better compared with winter cereal stands, and a shorter growing season result in an establishment in such stands of communities dominated by species characteristic of tuber and root crops [20-22]. In spring cereal stands in the Łuków Plain area, it was the community which included species characteristic of Panico-Setarion and the intermediate community Aperion spicae-venti with Polygono-Chenopodion species. From the standpoint of phytosociology they occupy the intermediate position between winter cereal and tuber and root crop associations [23]. These communities quite often include Aperion spicae-venti and Centauretalia cyani species, too, so most authors have focused only on their floristic similarity to the group of cereal communities without stressing their floristic distinctness [15,17,24-28]. However, Kozak [29] have classified spring cereal communities as the communities which are the same as those in tuber and root crops, and stressed that they belong to the alliance PanicoSetarion. Skrajna and Skrzyczyńska [21], Rzymowska and Skrzyczyńska [20] and Skrajna et al. [30] have demonstrated the same attitude towards spring cereal communities and classified them as belonging to alliances of tuber and root associations of the Polygono-Chenopodietalia order.

In the intermediate zone between two communities, there establish patches with species characteristic of both the associations. Such phytocenoses in the area of the Łuków Plain were found on the border of the popular associations Arnoserido-Scleranthetum and Vicietum tetraspermae. An immediate contact of patches of associations characterized by a similar ecological amplitude is a natural and one of the most important factors leading to an establishment of such communities [18,21]. Anthropogenic factors include changes in agrotechnology and fragmentation of fields which makes it easier for weed diaspores spread [4,31]. Intermediate communities in other parts of Poland have been reported for example by: Anioł-Kwiatkowska [15], Wnuk [26], Szmeja [32], Kozak [29], Skrzyczyńska and Marciniuk [17], Rzymowska and Skrzyczyńska [20], Skrajna and Skrzyczyńska [21], Skrajna et al. [30].

3. Warcholińska AU. Współczesne przeobrażenia zbiorowisk segetalnych w środkowej Polsce. Acta Agrobot. 1979;32(2):239-269.

4. Hołdyński C. Flora segetalna, zróżnicowanie florystyczno-ekologiczne i przemiany szaty roślinnej pól uprawnych w aktualnych warunkach agroekologicznych Żuław Wiślanych. Acta Acad Agric Tech Olst Agric. 1991;51(403);1-51.

5. Wnuk Z. Zbiorowiska segetalne Wyżyny Częstochowskiej na tle zbiorowisk segetalnych Polski. Zesz Nauk AR Krakow. 1988;125:5-33.

6. Kornaś J. Chwasty polne rozprzestrzeniane z materiałem siewnym. Specjalizacja ekologiczna i procesy wymierania. Zesz Nauk AR Krakow. 1987;216(19):23-36.

7. Korniak T. Flora segetalna północno-wschodniej Polski, jej przestrzenne zróżnicowanie i współczesne przemiany. Acta Acad Agric Tech Olst Agric. 1992;53(A suppl):5-76.

8. Korniak T. Ginące i zagrożone gatunki flory segetalnej w północnowschodniej Polsce. Acta Univ Lodz Folia Bot. 1998;13:43-50.

9. Anioł-Kwiatkowska J, Szczęśniak E, editors. Zagrożone archeofity Dolnego Śląska. Wrocław: Uniwersytet Wrocławski, Instytut Biologii Roślin; 2011. (Acta Botanica Silesiaca; supplementum 1) 
10. Szczęśniak E, Dajdok Z, Kącki Z. Metodyka oceny zagrożenia i kategoryzacja zagrożonych archeofitów na przykładzie Dolnego Śląska. Wrocław: Uniwersytet Wrocławski, Instytut Biologii Roślin; 2011. (Acta Botanica Silesiaca; Supplementum 1)

11. Adamczewski K, Kierzek R. Występowanie biotypów miotły zbożowej (Apera spica-venti L.) odpornej na herbicydy sulfonylomocznikowe. Prog Plant Prot Post Ochr Roślin. 2007;47(3):333-340.

12. Marczewska K, Rola H. Biotypes of Apera spica-venti and Centaurea cyanus resistent to chlorsulfuron in Poland. In: Proceedings of the 13th EWRS Symposium; Bari 19-23 June 2005. Bari: 2005. p. 197.

13. Marczewska-Kolasa K, Rola H. Methods of identification of Centaurea cyanus biotypes resistance to chlorsulfuron in south-west Poland. J Plant Dis Protect. 2008;21:91-94.

14. Wnuk Z, Dymon E, Grzebyk D. Zbiorowiska segetalne Rzeszowa. Zesz Nauk AR Krakow Rol. 2008;28:67-90.

15. Anioł-Kwiatkowska J. Zbiorowiska segetalne Wału Trzebnickiego. Florystyczno-ekologiczne studium porównawcze. Pr Bot. 1990;46:1-230.

16. Warcholińska AU. Klasyfikacja numeryczna zbiorowisk segetalnych Wzniesień Łódzkich. Łódź: Wyd. Uniw. Łódzkiego; 1990.

17. Skrzyczyńska J, Marciniuk J. Zbiorowiska segetalne rzędu Centauretalia cyani w granicach Siedlec. Acta Sci Pol Biologia. 2002;1(1-2):49-78.

18. Siciński JT. Agrofitocenozy dorzecza środkowej Warty i Bzury - stan, dynamika i zagrożenia. Łódź: Wyd. Uniw. Łódzkiego; 2003.

19. Węgrzynek B. Roślinność segetalna Wyżyny Śląskiej. Cz. 3. Zbiorowiska chwastów upraw zbożowych ze związku Caucalidion lappulae. Zubożałe zbiorowiska chwastów zbóż ozimych i jarych. Acta Biol Silesiana. 2003;37(54):120-150.

20. Rzymowska Z, Skrzyczyńska J. Zbiorowiska roślinne pól uprawnych Podlaskiego Przełomu Bugu. Cz. II. Zbiorowiska zbożowe. Acta Agrobot. 2006;59(2):377-391. http://dx.doi.org/10.5586/aa.2006.091

21. Skrajna T, Skrzyczyńska J. Zbiorowiska przejściowe i kadłubowe występujące w łanach zbóż Wysoczyzny Kałuszyńskiej. Acta Sci Pol Biologia. 2006;5(1-2):52-72.

22. Węgrzynek B. Roślinność segetalna Wyżyny Śląskiej. Cz. 2. Zbiorowiska chwastów upraw zbożowych ze związku Aperion spicae-venti. Acta Biol Silesiana. 2003;37(54):87-119.

23. Kornaś J. Zespoły synantropijne. In: Szafer W, Zarzycki K, editors. Szata roślinna Polski. Warsaw: Polish Scientific Publishers PWN; 1977. p. 442-465. (vol 1).

24. Anioł-Kwiatkowska J. Flora i zbiorowiska synantropijne Legnicy, Lubina i Polkowic. Acta Univ Wratisl Pr Bot. 1974;19:1-222.

25. Anioł-Kwiatkowska J, Nowak S. Flora i roślinność segetalna Parku
Krajobrazowego “Góra św. Anny” na Śląsku Opolskim. Pam Puł. 2006;5-16.

26. Wnuk Z. Zbiorowiska chwastów segetalnych Pasma PrzedborskoMałogoskiego i przyległych terenów. Cz. II. Zbiorowiska zbożowe i ścierniskowe. Acta Univ Lodz. 1976;14:123-177.

27. Wójcik Z. Zbiorowiska segetalne Pojezierza Suwalskiego. Fragm Flor Geobot Polonica. 2000;7:167-208.

28. Skrzyczyńska J, Marciniuk J. Zbiorowiska segetalne o charakterze pośrednim pomiędzy zespołami z rzędów Centauretalia cyani i Polygono-Chenopodietalia w granicach Siedlec. Acta Sci Pol Biologia. 2004;3(1):71-82.

29. Kozak M. Zbiorowiska segetalne gminy Rudniki (województwo opolskie). Fragm Flor Geobot Polonica. 2002;9:219-272.

30. Skrajna T, Skrzyczyńska J, Ługowska M. Segetal communities of cereal crops of the Mazowiecki Landscape Park. Acta Agrobot. 2009;62(1):171-186. http://dx.doi.org/10.5586/aa.2009.020

31. Szmeja K. Roślinność pól uprawnych Wzniesień Elbląskich. Acta Biol Med. 1989;7:1-66.

32. Szmeja K. Roślinność pól uprawnych Zaborskiego Parku Krajobrazowego. Fragm Flor Geobot Polonica. 1994;1:157-180.

\section{Zespoły i zbiorowiska upraw zbożowych Równiny Łukowskiej. Cz. III. Zbiorowiska przejściowe i zubożałe}

\section{Streszczenie}

Praca jest ostatnią, trzecią częścią opracowania poświęconego analizie zespołów i zbiorowisk zbożowych Równiny Łukowskiej. Przedstawiono w niej charakterystykę zbiorowisk zubożałych i pośrednich wykształcających się w uprawach zbożowych. Często na badanym terenie notowano płaty fitocenoz pozbawionych charakterystycznej kombinacji gatunków wyróżniającej zespoły zbożowe. W zasiewach zbóż ozimych były to zbiorowisko z Scleranthus annuus i zbiorowisko zubożałe ze związku Aperion spicae-venti. Zróżnicowanie florystyczne tych fitocenoz będące wyrazem zmienności siedliskowej było powodem wyróżnienia trzech postaci tego zbiorowiska: typowej, z udziałem gatunków higrofilnych i z gatunkami charakterystycznymi Polygono-Chenopodion. Natomiast w zbożach jarych wyróżniono fitocenozy z gatunkami typowymi dla upraw okopowych określone jako zbiorowisko $\mathrm{z}$ udziałem gatunków charakterystycznych $\mathrm{Pa}$ nico-Setarion oraz pośrednie zbiorowisko z gatunkami charakterystycznymi Aperion spicae-venti i Polygono-Chenopodion. Przyczyną wykształcania się takich zbiorowisk jest intensyfikacja produkcji prowadząca do zmiany warunków siedliskowych. Część płatów występujących na badanym terenie wykazywała charakter pośredni między dwoma najczęściej notowanymi zespołami Arnoserido-Scleranthetum i Vicietum tetraspermae, jako wynik ich bezpośredniego kontaktu w terenie. 